\title{
ON MEETING LINDA: AN INTIMATE ENCOUNTER WITH (NOT-) BELONGING IN THE CURRENT CONJUNCTURE
}

\author{
Sasha Roseneil
}

Psychoanalysis, Culture \& Society (2014) 19(1), 19-28.

Contact details:

Professor Sasha Roseneil

Department of Psychosocial Studies/ Birkbeck Institute for Social Research Birkbeck, University of London

Malet Street

London WC1E 7HX

s.roseneil@bbk.ac.uk 


\title{
On meeting Linda:
}

\section{an intimate encounter with (not-)belonging in the current conjuncture}

\author{
Sasha Roseneil
}

I was beginning my afternoon dog walk in Springfield Park, in the London Borough of Hackney, one crisp Saturday in November. I took the high route through the formal landscaped gardens, with the view across Walthamstow Marshes - the only wild open space left in East London, where cattle still graze, and where you can gather wild blackberries in the summer and occasionally glimpse dragonflies and water voles. Beyond the Marshes, you can see the Olympic Park with its shiny sculptural structures, and the glass expanses of the huge new shopping mall alongside it. But I went that way not for the view but because the wooded areas I would pass through offered more squirrel chasing possibilities for Candice, my squirrel-obsessed standard poodle.

As I walked along, I caught sight of a body, clad in candy-pink, on the ground amongst the trees. I stopped in my tracks, and left the path to look more carefully, to see if the person was breathing. I saw her chest rise and fall, and was momentarily relieved. But, it wasn't right that this woman was lying amongst the trees on a late November afternoon. The ground was damp, and the light would soon be fading. She wore black leggings with her pink sweatshirt, and had no socks on. Her bare ankles were touching the mulchy, muddy earth. Her arms were outstretched, and the leaves had been swept aside, as if she had been making angel wings in them.

“Are you alright?” I asked.

There was no reply.

I tried again. "Are you ok?"

The woman opened her eyes. "Not really", she said, remaining where she was. "I've been drinking".

"Oh, ok", I said, as the thought flickered across my mind: be careful about what you're getting into here, and I oh-so slightly backed away.

"Not really", she said again and looked up, lifting her head off the ground. Our eyes met. She was wearing a navy blue baseball cap, which said "Groovy Chick". She was short, and rather round, in her late 50s, probably. Her hair was thin and straggly, and she was missing a tooth. Her baggy sweatshirt was dirty and had leaves stuck to it.

"What's the matter?" I asked.

"I’ve tried to kill myself", she said. "I've tried, and it never works. I'm still here".

"Maybe a part of you doesn't want to die", I said, my voice rising at the end of the sentence in interrogative form, although I rather dreaded a negative answer.

"Yes, a part of me - you're right", she said. "But more of me does at the moment". 
"Life can be so hard", I said. "So hard".

The woman sat up. "It is", she said. "It is", echoing my repetition. We were starting to find each other.

We looked at each other.

"Isn't it a bit cold on the ground there?" I said.

"I like it here", she said. "I like the park, and the trees. I want to be with nature. I belong with nature, and animals".

I remembered Candice. "Oh gosh”, I said. "I just need to see where my dog is”.

I stepped back down to the path, and called for her. I could she her some way away. I called again, and she starting bounding back towards me. I went back to where the woman was.

"You've got a dog", she said, her voice a little brighter.

"Yes", I said. "She loves the squirrels here. She's off chasing them. I need to keep an eye on her".

"Where is she?" the woman asked. Candice hadn't appeared. I turned back to see what had happened to her.

"She's doing a poo over there", I said, and worried about whether I should break of the conversation to go and pick it up, or just carry on talking, and risk the wrath of fellow parkusers.

"That's nature", the woman said, almost smiling.

"Yes, it is", I said, and smiled back.

"I like being here", the woman said, "with the trees and the animals. They don't hurt you. They don't betray you".

"Have you got any animals?" I asked.

"Cats", she replied. "Sausage, Fluffy Tail and Maeve".

“Do you live nearby?” I asked.

"Yes, just up there". She gestured behind her - towards the large council estate that backs onto the park. "But I prefer it here. I just want to die when I go home".

"Have you talked to anyone about feeling like that?" I asked.

"No one cares", she said.

"What about your GP?"

“They don't care. I tried to get sectioned ${ }^{1}$, but they wouldn't section me. I'm bipolar. They don't care".

\footnotetext{
${ }^{1}$ Compulsorily detained under the Mental Health Act.
} 
"So you're having a down at the moment?"

"Yes", she said. She was crying now.

"Do you have a community mental health nurse", I asked, my knowledge of psychological services kicking in.

"I used to", she said. "But he left".

“And wasn’t replaced?” I asked.

She didn't answer.

She lay down again in the leaves, and began moving her arms up and down. Then she picked up some leaves and put them on her stomach.

"My mum and dad are dead". There were tears rolling down her cheeks. "And my brother's dead. And one of my sons just ignores me".

"That sounds hard", I said. "It's hard when your parents are gone".

She looked up again.

"My parents are dead", I said. "It's sad when they aren't around any more".

"I'm sorry", she said.

"It's ok. I get sad about it often", I said.

"Yes", she said. "I miss them. And my son's horrible to me".

"What does he do?" I asked.

"He's cruel to me", she said.

“How? What has he done?' I asked again.

"He hits me. He broke my leg a while ago. He pissed on me. He shouts at me. He hates me".

“That's not ok", I said. "Does he live with you?"

"Not anymore", she said. "I had to get rid of him. But he's been thrown out of his flat, for not paying his rent. And he's in trouble. And he comes and takes it out on me".

"Well, that isn't alright", I repeated.

"But he's my son. It's my fault".

"He's a grown-up man", I said. "You can't be responsible for his actions".

"He's my son". She was sobbing. "But he doesn't care. No one cares".

"I think you should talk to your GP”, I said. "Try to tell her how you are feeling”.

"I've tried. But I drink, and I'm bipolar", she said. "I'm an actress and poet, you know".

“Are you?” I said. 
"And I love nature. This is where I like to be. I love animals. I'm trying to be vegetarian, you know".

"I'm vegetarian", I said.

“Are you?” She perked up.

"Yes".

"It's hard. Do you find it hard?"

"Not really, but I've been vegetarian for a long time, all my life".

"Really? I am mostly, but - I shouldn't say it - she looked around, behind her, it's the bacon. I miss the bacon".

"You can get vegetarian bacon", I said. "I'm not sure how much it's like the real thing, but I like it".

"That's brilliant", she said.

She reached out her hand to me. "What's your name?"

"Sasha", I said.

"I'm Linda", she said.

We shook hands.

"I better see where my dog is", I said.

"Yes, yes", she said. "I love dogs".

I called Candice, more persistently this time, until she finally appeared. "Come and say hello to Linda", I said. Candice sniffed her way through the leaves, and came over.

Linda reached out to stroke her, smiling.

"Your cats need you", I said.

"Anyone could look after them", she replied.

"But you have a particular relationship with them. They know you".

"I suppose so", she said. "I do love them. Sausage, Fluffy Tail and Maeve".

She reached out her hand towards me again. "I'm Linda", she said. "What's your name?"

"I'm Sasha", I replied.

I put my hand in hers, to shake it again, and she kissed it.

"Thank you", she said. "Thank you for caring. I'm going to lie down here again, with nature".

"You take care", I said. "Don't get too cold". 
"I like it here", she said.

"Nice to meet you", I said, and called Candice. "We're off on our walk - got to find some more squirrels".

I cried as I walked down the path away from Linda, leaving her lying there under the trees, towards the Marshes to continue with my weekend. I cried for Linda in her isolation and loss, from the part of me that knows about isolation and loss, and who struggles to belong. Leaving her there was painful. I felt hopeless for her, and guilt surged through me, as it so often does: I was enacting yet another abandonment. I had my life to get on with, my comfortable home and supportive partner to go back to. It was alright for me. And I thought about the homeless people and the mentally ill people who were finding their way at the Occupy London camp at Finsbury Square, drawn by the possibility of being part of something, of finding people who care, who might care about them.

As I walked across the Marshes, I began my habitual work of churning experience over and turning it into the work that pays my salary and attaches me to institutions and networks within which I might sometimes feel I belong. And when I got home, I went straight to my computer and wrote (more or less) what you have just read.

$* * * * * *$

Linda's story, whilst more emotionally raw for being told from a supine position in the park, rather than across a kitchen table in a formal interview setting, was not so fundamentally different from some of the stories told to me by people I've interviewed in recent years, in research projects exploring practices of intimacy and care in three different places in northern England, and researching experiences of intimate citizenship in four European capital cities. In both these projects I was focusing on people living outside conventional couples and families - those who might be seen to be at the cutting edge of processes of social change, the individualisation and de-traditionalization of personal life. ${ }^{2}$ A significant number of these non-clinical samples had experienced moderate to severe mental health problems, particularly depression that I have described as intensely individualizing - producing a sense of isolation, aloneness and detachment from the social world and from particular relationships (Roseneil, 2007).

Linda's story, like my interviewees' stories of mental illness, reminds us of the psychic and relational vulnerability that is inherent in being human, and of the fundamental historical sociality of psychic life. Her story, as she told it to me, was one of loss, of severed attachments, and of gendered intimate violence. Her grief about the death of her parents seems to be part of what has unhinged her. If the modern western narrative and socio-legal reality of intergenerational relations is one in which children belong to parents, if we belong first to our parents, when parents die questions of belonging are thrown open. And, if the children who belong to Linda are a son who doesn't care, and a son who beats her, small wonder that she feels alone and desperate. No partner was mentioned, and we can only surmise that she is single. In the absence of intimate belonging, and perhaps in the context of

\footnotetext{
${ }^{2}$ See Giddens (1992) and Beck and Beck-Gernsheim (1995; 2002) for theorizations of individualization and the de-traditionalization of intimate life, and see Roseneil (2006; 2007; 2009) and Roseneil and Budgeon (2004) for empirical investigations and psychoanalytically informed reworkings of these theories.
} 
an organic psychiatric disorder, suicide beckons, the fantasy of escape from the pain of being alone.

Yet, some self-preservative impulse, the small flicker of desire to survive that Linda admits to when I ask about it, led her to try to get sectioned. She sought the security of a locked wing, of an institutional context with clear boundaries that might offer respite from her pain. But the welfare state failed her: she could not get herself sectioned. Being suicidal in these days of austerity and welfare cuts is not enough. After two decades of "community care", and the closure of dozens of psychiatric hospitals, without posing a real and present danger to others, Linda could not find the asylum she sought. She had even lost her community nurse; she had fallen through the ever widening cracks in the care system.

As well as vividly conjuring a psychosocial ontology of human relational vulnerability, my encounter with Linda draws attention to the modes of belonging that are made possible, or hindered, by particular configurations of the social, by specific types of state and civil society formation, and ways of organising welfare. Linda attempted to get help from the National Health Service, which despite being almost universally loved for its delivery of free health care to every resident of the United Kingdom, is also an institution that consistently fails its users. Almost every week, the news media report the uncovering of systemic and systematic failures to provide good enough care to people in the most vulnerable of states - the elderly, the disabled, the mentally unwell. These failures constitute a statement about the nonbelonging of such people - their exclusion, or at least their slippage, from the category of the worthy welfare subject. ${ }^{3}$ An uncoupled late middle aged woman, who drinks despite a psychiatric condition that would indicate abstention from alcohol during depressive periods, is far from being a worthy welfare subject. She has no children for the contemporary futureoriented, child-focused "social investment state" (Jenson and Saint-Martin, 2003; Jenson, 2009) to concern itself with, and she is not behaving as the ideal, responsiblised patient now so valorized by the active citizenship model of contemporary welfare governance (Newman, 2001; Dwyer, 2004; Clarke, 2005; Newman and Tonkens, 2011). ${ }^{4}$ She is, most likely, one of the "hard", if not "impossible to help" welfare users, so dreaded by health practitioners and social workers, whom many tend to end up designating - often as their own psychic survival strategy - as self-excluding, the architects of their own misfortune, lost causes in their nonbelonging (Scanlon and Adlam, 2008). If my own instinctive, if momentary, recoil from her when she told me of her drinking, and my sense of hopelessness as I left her lying on the ground is indicative of how others might respond to her, I could imagine how her isolation and outsider-status are repeatedly reconstituted, as she desperately reaches out for help and yet constantly sabotages it.

And then there is the question of Linda's non-belonging to her locality. Hackney, where Linda lives, is one of the most deprived but rapidly gentrifying and economically polarizing boroughs in London, and Clapton, her neighbourhood, is a highly diverse place. The most obvious local population is the large and extremely tight-knit Chassidic community, who occupy a large proportion of the housing around Springfield Park. I had a strong sense from Linda's admission of her love of bacon, and her gesturing around her as she spoke, that the local Chassidic community is a significant point of reference - an aspect of her nonbelonging. The exact contours of this I cannot know - whether Linda is or isn't Jewish, how

\footnotetext{
${ }^{3}$ On the long history of the construction of worthy and unworthy, deserving and undeserving welfare subjects in England, see Mann (1992).

"For a convincing argument that "social investment" rather than "neoliberalism" is the organising principle of contemporary European (and many Latin American) welfare state, see Jenson (2009).
} 
she relates to her Chassidic neighbours, how she feels about living amongst groups and families with such strong boundaries, would be a matter of speculation. But Linda seems not to feel a sense of belonging to the place in which she lives, or the people around her.

Instead, and this brings me to my final point, Linda emphasised repeatedly that her primary attachment is to the non-human - to "nature and the animals". She comes to the park, to the beautiful Edwardian legacy of a great era of civic planning and public works that provided this "lung of East London", to lie under the trees, amongst the leaf litter, to feel connected, to belong. Indeed, she is even trying to be vegetarian - an assertion of ethical connection to the animals she loves. This striving for connection, for a relationship with the non-human world, to feel part of something beyond her self, again echoes the stories of many of the people I interviewed in my research who sought a connection with the natural world, and who often found their place, their peace and serenity, a sense of ethical connection through walks on the moors, digging their gardens and growing plants and vegetables, and caring for dogs and cats (Roseneil, 2007). This suggests that in thinking about being together, about the psychosocial dynamics of belonging, we need to look beyond the human world to think about relations with the non-human world.

$* * * * * * * * * * * * * * * * *$

Transient encounters in public places, strangers meeting in a park, glimpses of other lives, connections made between people, and across species - such moments might offer us, if we linger with them, fragments of material from which to craft affectively attuned, psychosocial understandings of belonging and not belonging in the contemporary conjuncture.

\section{References}

Beck, U. and Beck-Gernsheim, E. (1995) The Normal Chaos of Love Cambridge, Polity Press.

Beck, U. and E. Beck-Gernsheim (2002) Individualization London, Sage.

Clarke, J. (2005) 'New Labour's citizens: activated, empowered, responsibilized, abandoned?" Critical Social Policy Vol.25 (4): 447-463.

Dwyer, P. (2004) "Agency, 'dependency' and welfare: beyond issues of claim and contribution?", in H. Dean (eds) The Ethics of Welfare. Bristol, Policy Press.

Giddens, A. (1992) The Transformation of Intimacy: Sexuality, Love and Eroticism in Modern Societies (Cambridge: Polity Press).

Jenson, J. and D. Saint-Martin (2003) "New Routes to Social Cohesion? Citizenship and the Social Investment State" The Canadian Journal of Sociology / Cahiers canadiens de sociologie, Vol. 28, No. 1: pp. 77-99

Newman, J. (2001) Modernising Governance: New Labour, Policy and Society. London, Sage.

Newman, J. and E. Tonkens (eds) (2011) Participation, responsibility and choice: summoning the active citizen in Western European welfare states. Amsterdam, Amsterdam University Press.

Roseneil, S. (2006) 'The Ambivalences of Angel's “Arrangement”: A Psycho-social Lens on the Contemporary Condition of Personal Life', The Sociological Review vol. 54, no. 4, 84769

Roseneil, S. (2007) 'Queer Individualization: The Transformation of Personal Life in the Early 21st Century' NORA: Nordic Journal of Women's Studies International Forum vol. 15, no. 2-3, 84-99. 
Roseneil, S. (2009) Haunting in an Age of Individualization: Subjectivity, Relationality and the Traces of the Lives of Others European Societies vol. 11, no. 3, 411-30.

Roseneil, S. and Budgeon, S. (2004) 'Cultures of Intimacy and Care Beyond "the Family": Personal Life and Social Change in the Early 21st Century', Current Sociology, vol. 52, no. 2, 135-59.

Scanlon, C. and J. Adlam (2008) "Refusal, social exclusion and the cycle of rejection: a cynical analysis" Critical Social Policy Vol.28 (4):529-549. 